\title{
Permeation of roxarsone and its metabolites increases caco-2 cell proliferation
}

\author{
Gladys S. Bayse ${ }^{1 *}$, Latanya P. Hammonds-Odie ${ }^{2 \#}$, Kimberly M. Jackson ${ }^{1}$, Deidre K. Tucker ${ }^{1}$, \\ Ward G. Kirlin ${ }^{3}$ \\ ${ }^{1}$ Department of Chemistry, Spelman College, Atlanta, USA \\ ${ }^{2}$ Department of Biology, Spelman College, Atlanta, USA \\ ${ }^{3}$ Department of Pharmacology and Toxicology, Morehouse School of Medicine, Atlanta, USA \\ Email: ${ }^{\text {Ihammond@ggc.edu }}$ \\ Received 23 June 2013; revised 20 July 2013; accepted 27 July 2013 \\ Copyright (C) 2013 Gladys S. Bayse et al. This is an open access article distributed under the Creative Commons Attribution License, \\ which permits unrestricted use, distribution, and reproduction in any medium, provided the original work is properly cited.
}

\section{ABSTRACT}

The benzenearsonate, Roxarsone, has been used since 1944 as an antimicrobial, growth-promoting poultry feed additive. USGS and EPA report that Roxarsone

(4-hydroxy-3-nitrobenzenearsonate) and metabolites, including AHBA (3-amino-4-hydroxybenzenearsonate), contaminate waterways at greater than 1100 tons annually. To assess human impact of these organic arsenic water contaminants, it was important to study their potential absorption. The human adenocarcinoma cell line, Caco-2, is a model for intestinal absorption. We found proliferative effects on Caco-2 cells at micromolar levels of these compounds, as monitored by $\left[{ }^{3} \mathrm{H}\right]$-thymidine incorporation into DNA. Flow cytometry cell cycle analysis confirmed accumulation in $S$ phase from $21 \%$ (control) to $36 \%$ (24 hour exposure to $10 \mu \mathrm{M}$ AHBA). Confluent Caco-2 cells grown on collagen-coated Transwell plates were dosed on the apical side. After exposure, media from apical and basolateral sides were collected separately. Following removal of $F B S$ by $30 \mathrm{~K}$ centrifugal filtration, the benzenearsonates in the collected media were analyzed by HPLC. Analyses were at wavelengths in the ultraviolet/visible range where the absorbance values were linear with respect to concentration. Concentrations were calculated by comparison with analytically-prepared commercial standards. Results from cells dosed at $10 \mu \mathrm{M}$ for 24 hours with AHBA, Roxarsone, or Acetarsone indicated $6 \%$ - $29 \%$ permeation occurring from apical to basolateral side, modeling absorption across intestinal epithelium to the circulatory system. Benzenearsonate feed additives are frequently applied in combination with antibiotics, raising addi-

*Dr. Gladys Bayse deceased suddenly on July 25th, 2013.

\#Corresponding author. tional health concerns. We conclude that micromolar levels of these benzenearsonates are adequate to stimulate Caco-2 cell proliferation.

Keywords: Benzenearsonates; Roxarsone; Phenylarsonates; Arsenicals; Caco-2

\section{INTRODUCTION}

The number of concentrated animal feeding operations (CAFOs) has increased in the US since the late 1980s. Governmental agencies and public health groups have indicated that farming practices account for declining water quality in the US [1,2]. From the 1940s, benzenearsonates have been used as approved feed additives to prevent infections and to promote growth in commercially grown poultry and swine [3]. Roxarsone (4-hydroxy-3nitrobenzenearsonate) is the major feed additive used for broiler production [4]. Roxarsone and its metabolites are primarily excreted, adding more than 1100 tons per year to waterways, especially downstream from CAFOs [5-7]. Additionally, poultry litter (excrement, spilled feed, cage straw) is frequently used as fertilizer [8]. Some states have recently banned or decreased poultry litter use as fertilizer, but enforcement procedures are not clear $[9,10]$. The highest density of poultry CAFOs exists in the Delmarva Peninsula (Delaware, Maryland, and Virginia), the Ozark Plateau (Arkansas, Oklahoma, Missouri, and some areas of eastern Texas), Georgia, and the Carolinas [5]. The areas downstream of poultry CAFOs where the populations' drinking water is provided by the local groundwater are of particular concern [11].

The Roxarsone reduction product, AHBA (3-amino-4hydroxybenzenearsonate), has been identified by poultry excretions [12] and produced by anaerobic bacterial 
action [13]. The structural formulas for Roxarsone biotransformations to the reduced AHBA and N-acetylated Acetarsone are shown in Figure 1. Several studies have revealed rapid AHBA and inorganic arsenic (iAs) production from Roxarsone, using both chicken litter and anaerobic microbial-containing sludge [13].

A pure Clostridium strain has been reported to reduce Roxarsone to AHBA [14]. Aromatic amines such as AHBA easily form azides that are usually toxic and often carcinogenic $[15,16]$. We previously observed that the Roxarsone metabolite, AHBA, can be N-acetylated to Acetarsone (3-N-acetylamino-4-hydroxybenzenearsonate) in vitro by cloned human $\mathrm{N}$-acetyltransferase 1 [17]. The acetylation rate of AHBA to Acetarsone is slow when compared to the model substrate, $p$-aminobenzoic acid, and to the swine feed additive, Arsanilate [18]. Acetarsone had three times the toxicity of Roxarsone in the rodent model [19].

The FDA recommendation to reduce the use of Roxarsone in poultry feed may impact water contamination downstream from CAFOs [20]. However, investigators have shown that years of soil penetration by Roxarsone and its metabolites is such that leaching into ground water is likely to continue for some time [5,7]. Chronic exposure of humans to such arsenic-containing compounds, especially in the water supply, is a matter of serious concern. The nature of the organic moiety in feed additives is also of concern, since structurally similar aromatic compounds can be metabolized to active electrophiles, potentially reacting with DNA and proteins to cause tissue necrosis and/or to form mutagens [21,22].

This laboratory has reported proliferative effects of these compounds both on freely cycling and on synchronized Caco-2 cells, the human colon adenocarcinoma cell line [17,23-26]. These observations were confirmed by using flow cytometry analysis after dosing the cells with micromolar levels of Roxarsone, AHBA, and Acetarsone [23]. In this report, we tested the hypothesis that if benzenearsonates are present in drinking water, these compounds can be absorbed upon ingestion. Data in our preliminary reports indicated that concern over potential human impact of benzenearsonates in drinking water was justified $[17,23]$. Thus, we postulated that it was important to study their absorption and possible metabolism by intestinal epithelial cells. The Caco-2 cell line is a model frequently used for that purpose by the pharmaceutical industry [27-29]. Caco-2 cells are adherent and are extensively used for permeability studies involving Transwell devices. In an effort to mimic absorption from the intestinal lumen across the epithelial monolayer into the circulatory system, we dosed Caco-2 cell on the apical side with the benzenearsonates, Roxarsone, AHBA and Acetarsone.

\section{MATERIALS AND METHODS}

\subsection{Chemicals}

Roxarsone and AHBA were obtained from Pfaltz and Bauer, Inc. (Waterbury, CT). Acetarsone, RNase A, and propidium iodide were obtained from Sigma-Aldrich (St. Louis, MO). HPLC grade water was purchased from ThermoFisher Scientific Co., Suwanee, GA. The human colon adenocarcinoma Caco-2 cell line, Eagle's MEM (EMEM) growth media and Fetal Bovine Serum (FBS) were obtained from American Type Culture Collection (Manassas, VA).

\subsection{Supplies}

Microsep 30K centrifugal microconcentrators from Pall Life Sciences were purchased from VWR Scientific Co. (Suwanee, GA) and were used to remove FBS from culture media prior to LC analysis. Centrifugation was at $5^{\circ} \mathrm{C}$ and $5000 \times \mathrm{g}$. Transwells were a product of Corning Costar Corp. (Tewksbury, MA) and were a 6 well format of 0.4 micron pore size with collagen coated PTFE membranes. The Whatman $4 \mathrm{~mm}$ syringe filters with a pore size of 0.45 microns were purchased from ThermoFisher.

\subsection{Cell Culture for Proliferation, Cell Cycle Analysis and Transwell Studies}

Cells were cultured in EMEM media supplemented with $20 \%$ FBS, $100 \mathrm{U} / \mathrm{ml}$ penicillin G, $100 \mu \mathrm{g} / \mathrm{ml}$ streptomycin, $0.25 \mu \mathrm{g} / \mathrm{ml}$ amphotericin $\mathrm{B}, 1.0 \mathrm{mM}$ sodium pyruvate, and $2.0 \mathrm{mM} \mathrm{L}$-glutamine and incubated in a humidified $5 \% \mathrm{CO}_{2}$ atmosphere at $37^{\circ} \mathrm{C}$. Cell viability was determined microscopically by exclusion of Trypan Blue. Prior to treatment with benzenearsonates, cells used in the proliferation and cell cycle analysis studies were gradually serum deprived to zero over a four-day period, followed by addition of $20 \%$ serum to synchronize the cells to move from $\mathrm{G}_{0}$ into the proliferative phase of the cell cycle.

\subsection{Cell Proliferation}

Cultures were replicated in quadruplicate on ninety-six well plates, seeded with $0.5,1.0$, and $2.0 \times 10^{4}$ cells, synchronized and at $70 \%-80 \%$ confluence, were exposed to micromolar concentrations of Roxarsone, AHBA, and Acetarsone for 16 and 24 hour periods. Cells were then incubated with $\left[{ }^{3} \mathrm{H}\right]$-thymidine for 6 hours and harvested (Skatron Cell Harvester, Sterling, VA) onto glass fiber filters. The filters were placed in scintillation vials. Radioactivity incorporated into DNA was determined by a scintillation counter as a relative measure of cell proliferation and expressed as percent of control, desig- 
nated as $100 \%$. For tightness of replicates, data were analyzed by coefficient of variation (standard deviation/ mean).

\subsection{Cell Cycle Analysis by Flow Cytometry}

Caco-2 cells were replicated in triplicate in six well plates and seeded with $2.0 \times 10^{4}$ cells, synchronized and at $70 \%$ to $80 \%$ confluence exposed to $10 \mu \mathrm{M}$ Roxarsone, AHBA, and Acetarsone for 16 and 24 hour periods. Cells were harvested, separated from media by centrifugation and fixed at $-20^{\circ} \mathrm{C}$ with $70 \%$ ethanol overnight. The cells were then pelleted by centrifugation, resuspended in $1 \mathrm{ml}$ of PBS containing $1 \mathrm{mg} / \mathrm{ml}$ of glucose, $1 \mathrm{mg} / \mathrm{ml}$ of RNase A and stained with $50 \mu \mathrm{g} / \mathrm{ml}$ of propidium iodide. A FACS Calibur equipped with dual argon-ion lasers (Becton-Dickinson Immunocytometry Systems, San Jose, CA) was used to perform flow cytometry and data were recorded, stored, and analyzed by ModFit-LT (Verity Software House) and Cell Quest software (Becton-Dickinson).

\subsection{Transwell Studies}

Cultures were grown to about $90 \%$ confluence on collagen-coated membranes as determined by microscopic inspection and measurement of electrical resistance. The cultures typically required about 14 days of culture to reach confluence. The electrical resistance was measured using "chopstick electrodes" with an Evometer (World Precision Instruments, Sarasota, FL). The blank well served as reference for the electrodes and the desired reading prior to dosing was about $170 \mathrm{ohms}$ (resistance readings were stable over the 48 hour treatment period). The control wells were not dosed, however were processed as indicated below. The confluent monolayers were dosed with $10 \mu \mathrm{M}$ Roxarsone, AHBA, or Acetarsone in the complete media for 12, 24, or 48 hour periods. After incubation, media on the apical and basolateral sides were collected into separate tubes. Then centrifugal filtration was used to remove FBS. Basolateral media samples were concentrated 5-fold and filtered through 0.45 micron nylon filters, before injection onto the HPLC systems. The absorbance of samples from the control wells, at the HPLC wavelengths and retention times indicated, were subtracted from the benzenearsonate experimental sample absorbance values, when determining concentrations. Apical media samples were analyzed without concentration or filtration through 0.45 micron filters. The amounts of Roxarsone, AHBA, and Acetarsone in both basolateral and apical media were analyzed. The $10 \mu \mathrm{M}$ dose in a $1.5 \mathrm{ml}$ volume (apical) equals 15 nmoles. Three independent experiments were conducted, each of triplicate wells dosed with Roxarsone, AHBA or Acetarsone.

\subsection{HPLC}

The HPLC System (ThermoSeparations Products, Riviera Beach, FL) was a C-18 Aquasil column (ThermoElectron, Bellefonte, PA), $4.6 \times 250 \mathrm{~mm}$, with a mobile phase of $17 \mathrm{mM}$ ammonium acetate buffer $\mathrm{pH} 6.0$, a flow rate of $1 \mathrm{ml} / \mathrm{min}$, and a variable wavelength ultraviolet/visible detector. For injected samples, Roxarsone was detected at $290 \mathrm{~nm}$ or $400 \mathrm{~nm}$ with a retention time of 3.5 minutes; AHBA at $290 \mathrm{~nm}, 3.2$ minutes; and Acetarsone at $245 \mathrm{~nm}, 4.5$ minutes. The absorbance of samples from the control wells was analyzed at the indicated wavelengths for each compound and subtracted from the dosed benzenearsonate absorbance values, when determining concentrations. A minimum of 4 injections from each of the apical and basolateral triplicate wells from the Transwell experiments were analyzed. Concentrations were determined by peak height comparison with the three commercial standards prepared at $10 \mu \mathrm{M}$.

\subsection{Statistical Analysis}

One-way ANOVA and Newman-Keuls analysis were used to determine the significance in Roxarsone permeation over time.

\section{RESULTS}

There are several literature reports of Roxarsone and two metabolic products, the nitro-reduced AHBA arising from microbial sources [13], and the N-acetylated Acetarsone from animal [12] and human sources [23]. These three compounds, Roxarsone, AHBA and Acetarsone (Figure 1), are the focus of data presented here on proliferative effects, flow cytometry analysis, and Transwell studies, employing the Caco- 2 cell culture model. The proliferative effects of Roxarsone, AHBA, and Acetarsone on synchronized Caco-2 cells were examined using two independent methods, cell proliferation monitored by $\left[{ }^{3} \mathrm{H}\right]$-thymidine uptake and cell cycle analysis using flow cytometry. $\left[{ }^{3} \mathrm{H}\right]$-thymidine uptake into DNA as described in MATERIALS AND METHODS was used as a measure of DNA synthesis primarily occurring during

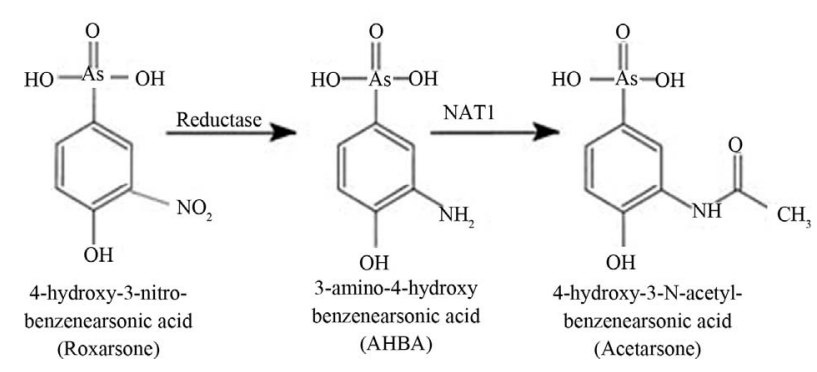

Figure 1. Structural formulas of roxarsone, AHBA, and Acetarsone. 
the $\mathrm{S}$ phase of the cell cycle. Proliferation values resulting from exposure to each compound for 16 and 24 hour over the $0.2-10 \mu \mathrm{M}$ dose range, expressed as percent of control are shown (set as 100\%; Figure 2). After 16 hours of exposure, all three compounds resulted in slight increases over the control.

Likewise, after 24 hours, all compounds at all dose levels caused increases, ranging from 111 to 164 percent relative to control values (Figure 2). AHBA was consistently the greatest stimulator of proliferation at 24 hours at all tested doses. Flow cytometry analysis was used also to evaluate the proliferative potential of Roxarsone and its two metabolites. Flow cytometry data for synchronized Caco-2 cells exposed to all three compounds at $10 \mu \mathrm{M}$ for 24 hours are shown in Figure 3. In the

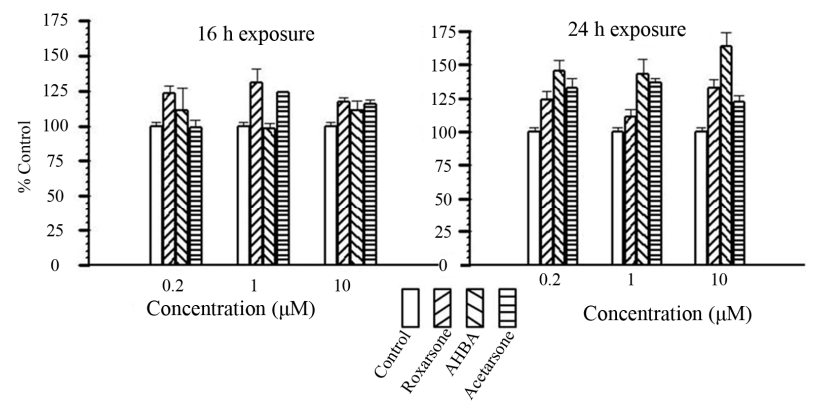

Figure 2. Caco-2 cell proliferation in response to $0.2-10 \mu \mathrm{M}$ Benzenearsonates for 16 and 24 hours. Left to Right: Control, Roxarsone, AHBA, Acetarsone (as indicted by bar patterns in legend). Bars indicate percent of control rates of proliferation, expressed as Mean $+/-$ SE from a sample size of $n=3$ (4 replicates per $n$ ).

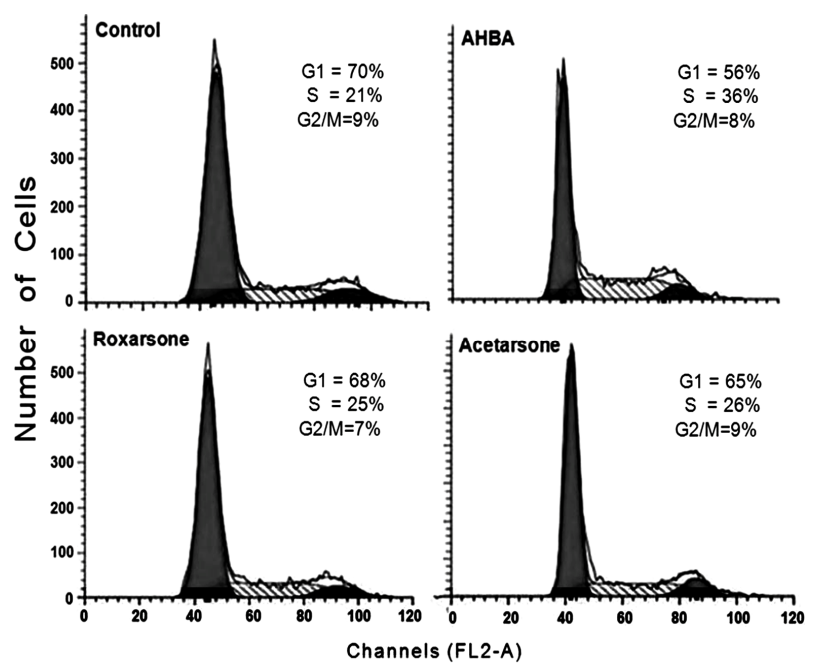

Figure 3. Flow cytometry data for Caco-2 cells dosed with Roxarsone, AHBA, and Acetarsone (10 $\mu \mathrm{M}, 24$ hours). Caco-2 cells were exposed to $10 \mu \mathrm{M}$ benzenearsonates for 24 hours, and then processed for cell sorting according to the procedure described in Materials and Methods. Average percentage of cells $(n=3)$ from 3 independent experiments. presence of AHBA, there was a noticeable increase in the percentage of cells in $\mathrm{S}$ phase of the cell cycle correlating with increased cell proliferation (Figure 2). Neither Roxarsone nor Acetarsone significantly altered the proportion of cells in these cell cycle phases compared to control treatments (Figure 3). The data from both the $\left[{ }^{3} \mathrm{H}\right]$-thymidine uptake and the flow cytometry experiments indicated that AHBA increased the proliferation of synchronized Caco-2 cells.

To investigate the ability of Roxarsone, AHBA, and Acetarsone to readily transverse a monolayer of epithelial cells, Transwell studies using Caco-2 cells were performed. The results of these Transwell studies in which Caco-2 cells were treated for 24 hours with $10 \mu \mathrm{M}$ (15 nmol) of one of the benzenearsonates administrated to the apical side of the monolayer are shown in Table 1. For Roxarsone and Acetarsone, the apical and basolateral compartments' amounts totaled approximately $15 \mathrm{nmol}$, which is equivalent to the original $10 \mu \mathrm{M}$ applied dose. This implied that no net metabolic conversion of these compounds occurred in the Caco- 2 cells during the 24 hour incubation period for the Transwell studies, but that these compounds readily transversed the epithelial monolayer. At 24 hours, the percent permeation from apical to basolateral sides was somewhat different between the compounds, $25 \%$ (3.78 $\pm 0.19 \mathrm{nmol})$ of dosed Roxarsone and $29 \%(4.37 \pm 0.20 \mathrm{nmol})$ of dosed Acetarsone (Table 1). AHBA exhibits only $6 \%$ permeation $(0.87 \pm 0.21$ nmol) from apical to basolateral sides. The apical side retained $49 \%$ of the original AHBA dose, giving a total recovery of $55 \%$ of the $15 \mathrm{nmol}$ dose (Table 1). Recovery of dosed AHBA presented analytical challenges and we have been unable to account for the total dosed amounts. However, plots (not shown) of 24 and 48 hour dosing for AHBA and for Acetarsone indicated time-dependent migration. The permeation by Roxarsone across the Caco- 2 monolayers showed time-dependent linearity at 12, 24 and 48 hour exposure to the $15 \mathrm{nmol}$ dose (Figure 4).

Table 1. Degree of permeation of Caco-2 cells by $10 \mu \mathrm{M}$ (15 nmol) doses of Roxarsone, AHBA, and Acetarsone after 24 hours exposure.

\begin{tabular}{cccc}
\hline & Roxarsone & Acetarsone & AHBA \\
\hline $\begin{array}{c}\text { Basolateral } \\
\text { Permeation, nmol }\end{array}$ & 3.78 & 4.37 & 0.87 \\
SE & 0.19 & 0.20 & 0.21 \\
$\underline{\text { Apical }}$ & & & \\
Concentration, nmol & 11.01 & 10.64 & 7.41 \\
SE & 0.35 & 0.35 & 0.58 \\
\hline
\end{tabular}




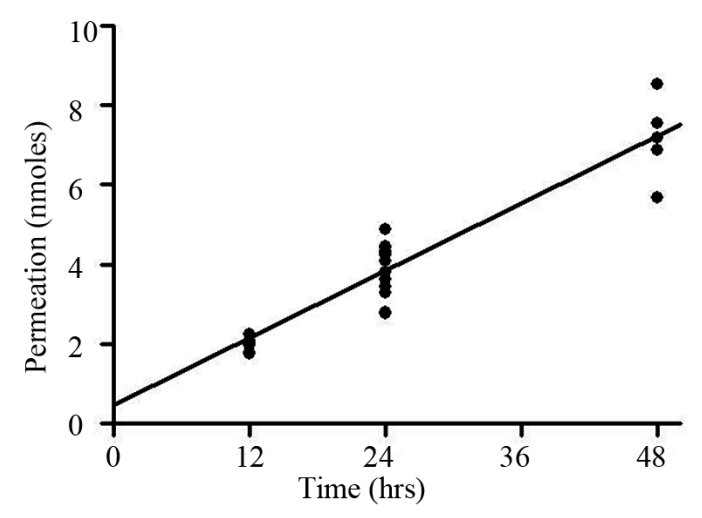

Figure 4. Permeation rate of Roxarsone $(15 \mathrm{nmol})$ from apical to basolateral membrane of Caco-2 cells over 12-48 hours of exposure. Amount of Roxarsone measured on basolateral side of membrane 12, 24 and 48 hours after administration to the apical side in Transwell studies described in Materials and Methods. One-way ANOVA indicated significant changes in Roxarsone amounts between time points and NewmanKeuls indicated significant differences between each time point $(\mathrm{p}<0.001)$.

\section{DISCUSSION}

This country's food supply is regulated at the federal level and considered generally safe in comparison with other countries. However, the food supply contains several thousand additives in trace amounts, including veterinary pharmaceuticals and feed additives, in the case of animal products. A large percent of consumable animal protein comes from animals exposed to "medicated" feeds for part of their lives [30]. Most poultry farms in the United States have used Roxarsone as a feed additive [8]. Approval was given by the FDA in 1944 for its use to treat coccidiosis and improve growth in broilers. The National Toxicology Program data raised concerns because of toxicity in rats $(200 \mathrm{ppm})$ and mice $(800 \mathrm{ppm})$ exposed to Roxarsone in a thirteen week study [31] and because of positive results with Roxarsone in Salmonella mutagenicity tests [32]. In addition, there has been largescale contamination of waterways by feed additives and metabolites due to the trend from the 1980s toward concentrated animal feeding operations [16].

A major USGS paper on organic water contaminants in urban areas did not contain the planned analysis of Roxarsone content due to incompatibility with the analytical methods in the study [1]. Until recently, chicken litter (excrement, spilled food, and cage straw) was widely used as fertilizer on the same farms, leading to further pollution of soil and groundwater. Several states began to decrease or monitor the use of litter as fertilizer but the extent of enforcement at the time was unclear $[2,9,33]$. Concerns were also expressed by several investigators regarding the leaching of Roxarsone from such fertilized soil ultimately into groundwater [5-7].

Microbial action on Roxarsone to produce AHBA has been reported from several studies. Recent papers using anaerobic microbial-containing sludge and Clostridia strains known to be in chicken litter reveal both AHBA and iAs production from Roxarsone $[13,14]$. In spite of the above concerns, the July 2010 Federal Register summary notice (21CFR 558.530) still gave approval for continued use of Roxarsone as a feed additive for poultry, turkeys and swine [3]. However, following additional analyses of iAs content of chicken livers reported by the FDA, the major commercial manufacturer in the United States, Alpharm, Inc., a subsidiary of Pfizer, voluntarily suspended sales of Roxarsone (3-Nitro) in July 2011 [20].

In the current studies, the proliferative effects of Roxarsone and its metabolites, AHBA and Acetarsone, on Caco-2 cells were examined. While all three compounds resulted in increased DNA synthesis as monitored by $\left[{ }^{3} \mathrm{H}\right]$-thymidine uptake (Figure 2), only AHBA caused a notable increase in the percentage of cells accumulating in S phase (Figure 3) as measured using flow cytometry. The potential for human health impacts of Roxarsone and its metabolites hinges on absorption of these compounds from ingesting contaminated drinking water. For all three benzenearsonates, permeation occurred at the 10 $\mu \mathrm{M}$ dosage level (Table 1). There was a linear relationship for transport across the epithelial monolayer of Caco-2 cells over the 12 to 48 hour treatment period for Roxarsone (Figure 4). The amount that permeated the monolayer is equivalent to $3.78 \pm 0.19 \mathrm{nmol}(25 \%)$ for Roxarsone, $4.37 \pm 0.20 \mathrm{nmol}(29 \%)$ for Acetarsone and $0.87 \pm 0.21 \mathrm{nmol}$ for AHBA (6\%; Table 1). The total amount of Roxarsone and Acetarsone detected in the apical and basolateral media samples from the Transwell studies approximated the dosed amounts, suggesting that there was no metabolic conversion of these benzenearsonates. In contrast, recovery of the dosed amount of AHBA was only $55 \%$. The possible oxidation products of AHBA to Roxarsone or potential $\mathrm{N}$-acetylation to Acetarsone were not detected in the media samples. Stoltz et al. [14] have noted from their electronic structure analysis that reduction of the nitro group of Roxarsone to the amine of AHBA is likely to occur before the loss of iAs from the ring. This recognizes the bond strength of the stronger aromatic carbon to arsenic (C-As) bond versus the alkyl C-As bond. Given the chemical reactivity of the AHBA molecule (Figure 1), even loss of water from the arsenate moiety would destabilize the ring, enhancing its cleavage. Such a reaction could explain our inability to account for all the AHBA in the Caco-2 Transwell studies (Table 1), since the HPLC detection of AHBA was by ultraviolet absorbance of its aromatic ring. 
Unfortunately, there have been no values reported for levels of these compounds in drinking water for comparison. The Caco-2 monolayer model mimics the potential absorption of compounds into the circulation [27-29]. After reaching the bloodstream, most substances travel to the liver. Our observed proliferative effects in human cell cultures raise concerns regarding the possibility of harmful products from hepatic enzyme activity. Proliferation may not be directly linked to tumorigenesis, but increased proliferation could result in increased sensitivity to carcinogens and/or mutagens [34]. We have observed oxidation of NADPH with AHBA as substrate and cytochrome P450 CYP3A4 as catalyst; but no product has yet been identified [23].

Continued study of these organoarsenical metabolites and their biological role(s) in increasing cell proliferation is essential and attention should be focused on possible products resulting from bioactivation. In animals, no enzyme has been isolated and characterized for the reduction reaction of Roxarsone to AHBA. However, aromatic nitro reduction is commonly attributed to liver CYPs, NADPH-quinone oxidoreductase, or intestinal anaerobic microbes [22]. Production of AHBA from Roxarsone by poultry had been reported many years ago, [12]. Evidence for anaerobic microbial conditions that produce AHBA from Roxarsone was provided [14]. Also, AHBA, the most proliferative metabolite in our studies, has an arylamine structure making it a candidate for DNA-adduct formation [35]. Possible metabolic reactions for AHBA could also produce a reactive nitroge $\mathrm{n}$ species, as a positively charged nitrene or a free radical [22]. Roxarsone and Acetarsone are also proliferative, but with lesser increases in S phase than AHBA.

Several authors have noted the dichotomy of arsenicals' medicinal benefit versus deleterious effects on cells and tissues. Information is scarce on aromatic nitro and amino compounds' specific roles in mutagenicity and carcinogenicity [32]. For example, in a study of human gastric cancer MGC-803 cells, Zhang et al. [36], found that Arsacetin (4-N-acetylbenznearsonate; N-acetylarsanilate) treatment resulted in increased protein kinase activity, apoptosis, p53 expression, and cell proliferation opposite results were obtained with micromolar levels of iAs $\left(\mathrm{As}_{2} \mathrm{O}_{3}\right)$. Other investigators have confirmed that micromolar levels of iAs caused DNA damage, cell arrest, and probable reduction of levels of cyclin/CDKs $[37,38]$. iAs at micromolar levels have public health outcomes in occurrence of cancers and metabolic diseases, endocrine disruption, and altered immune response [39-44].

The data presented here show transport of nanomole levels of benzenearsonate compounds by Caco-2 cells, with subsequent proliferative effects. The ultimate goal of this project is to elucidate the mechanism(s) that explain the proliferative effects of Roxarsone, AHBA, and
Acetarsone. As a consequence of the current awareness (FDA recommendations and the major manufacturer's halt in sale of Roxarsone) of the potential for longer term impacts on human health from the Roxarsone in poultry feed, the levels of it and its metabolites including iAs should decrease over time downstream from the CAFOs. Unfortunately, a recommendation to reduce the use of accumulated poultry manure as fertilizer or to stop the inclusion of Roxarsone in cattle feed, has not been forthcoming in this country. However, the years of soil permeation will continue to cause leaching of these arsenic containing compounds into drinking water for some time. Furthermore, any enforcement of regulations and recommendations on Roxarsone usage has been left to the states and concerns over human health impact appear not to have been addressed [9]. However, EPA will investigate if the Inspector General is alerted to abuses [10].

There exists a growing body of evidence from the scientific community that the increase in antibiotic resistant microbes is partly attributable to the widespread use and poorly controlled disposal of waste from animal feeding operations using arsenic-containing feed additive/antibiotic combinations [45-47]. A survey of the Code of Federal Regulations list for Roxarsone reveals that its approval for use in poultry and swine feed permits combinations with over twenty different antibiotics [48]. In light of their likely roles as drinking water contaminants with implications for human health, the continued approval and use of other organic arsenicals as animal feed additives (Arsanilate in swine and poultry feed, swine waste as fertilizer and Nitarsone and Carbasone as animal medicinals) need to be evaluated.

\section{ACKNOWLEDGEMENTS}

The authors would like to thank Brittney L. Thirkield for her assistance with manuscript preparation, Dr. Marisela De Leon Mancia for her technical assistance with and analysis of the flow cytometry studies, Aisha Rollins-Hairston for her technical assistance with the $\left[{ }^{3} \mathrm{H}\right]$-thymidine studies, and Dr. Cornelia D. Gillyard for her insight into organic mechanisms for benzenearsonates.

This work was supported by grants from the National Institute of General Medical Sciences at the National Institutes of Health [Grants GM008241 and 1SC3GM083747 to G.S.B.; Grant GM008241 to L.P.H.O. and Grant GM028248 to W.G.K.]; the National Center for Minority Health Disparities at the National Institutes of Health [Grant MD000215-SP0001 to K.M.J.]; L.P.H.O. and K.M.J. were supported as Scholar-Teachers [Minority Institutions of Excellence/National Aeronautics and Space Association NCC8-227]. Partial support was provided by the $\mathrm{CB}^{2} \mathrm{RSpelman}$ College Core Laboratory which has funding from the National Center for Minority Health Disparities at the National Institutes of Health [Grant MD00215]. Neither the NIH nor NASA had a role in study design; in the collection, analysis and inter- 
pretation of data; in the writing of the report; and in the decision to submit the article for publication.

\section{REFERENCES}

[1] Kolpin, D.W., et al. (2002) Pharmaceuticals, hormones, and other organic wastewater contaminants in US streams: A national reconnaissance. Environmental Science \& Technology, 36, 1202-1211. doi:10.1021/es020136s

[2] Osterberg, D. and Wallinga, D. (2004) Addressing externalities from swine production to reduce public health and environmental impacts. American Journal of Public Health, 94, 1703-1708. doi:10.2105/AJPH.94.10.1703

[3] US Food and Drug Administration (2010) 21 CFR Part 558.530. Food and drugs: new animal drugs for use in animal feeds. Electronic code of federal regulations. http://www.gpo.gov/fdsys/pkg/CFR-2010-title21-vol6/x ml/CFR-2010-title21-vol6-part558.xml\#seqnum558.530

[4] Calvert, C.C. (1975) Arsenicals in animal feeds and wastes. In: Woolson, E.A. Ed., Arsenical Pesticides, American Chemical Society, Washington DC, 70-79. doi:10.1021/bk-1975-0007.ch005

[5] Garbarino, J.R., Bednar, A.J., Rutherford, D.W., Beyer, R.S. and Wershaw, R.L. (2003) Environmental fate of roxarsone in poultry litter. I. Degradation of roxarsone during composting. Environmental Science \& Technology, 37, 1509-1514. doi:10.1021/es026219q

[6] Jackson, B.P. and Bertsch, P.M. (2001) Determination of arsenic speciation in poultry wastes by IC-ICP-MS. Environmental Science \& Technology, 35, 4868-4873. doi:10.1021/es0107172

[7] Rutherford, D.W., et al. (2003) Environmental fate of roxarsone in poultry litter. Part II. Mobility of arsenic in soils amended with poultry litter. Environmental Science \& Technology, 37, 1515-1520. doi:10.1021/es026222+

[8] Hileman, B. (2007) Arsenic in chicken production. Chemical and Engineering News, 85, 34-35. doi:10.1021/cen-v085n015.p034

[9] Cody, C. (2003) Siloam springs: Farmers told to stop spreading litter. Arkansas Democrat Gazette, 1.

[10] Joyner, C. (2011) Feds warn of potential water contamination. The Atlanta Journal-Constitution, 14, SA1-SA12.

[11] Nachman, K.E., Graham, J.P., Price, L.B. and Silbergeld, E.K. (2005) Arsenic: A roadblock to potential animal waste management solutions. Environ Health Perspectives, 113, 1123-1124. doi:10.1289/ehp.7834

[12] Moody, J.P. and Williams, R.T. (1964) The metabolism of 4-hydroxynitrophenylarsonic acid in hens. Food and Cosmetics Toxicology, 2, 707-710. doi:10.1016/S0015-6264(64)80422-3

[13] Cortinas, I., et al. (2006) Anaerobic biotransformation of roxarsone and related N-substituted phenylarsonic acids. Environmental Science \& Technology, 40, 2951-2957. doi:10.1021/es0519810

[14] Stoltz, J.F., et al. (2007) Biotransformation of 3-nitro-4hydroxybenzene arsonic acid and release of inorganic arsenic by Clostridium species. Environmental Science \&

\section{Technology, 41, 818-823. doi:10.1021/es061802i}

[15] Sabbioni, G. and Richter, E. (1999) Aromatic amines, nitroarenes, and heterocyclic aromatic amines. In: Marquardt, H., Schafer, S.G., McClellan, R.O. and Welsch, F. Eds., Toxicology, Academic Press, San Diego, 730-736. doi:10.1016/B978-012473270-4/50089-4

[16] Wershaw, R.L., et al. (2003) Mass spectrometric identification of an azobenzene derivative produced by smectitecatalyzed conversion of 3-amino-4-hydroxy-phenyl-arsonic acid to an azobenzene derivative. Talanta, 59, 12191226. doi:10.1016/S0039-9140(03)00032-8

[17] Bayse, G.S., Kirlin, W.G. and Kirkland, P.D. (2004) Effects of roxarsone and its metabolites on caco-2 cell proliferation. Toxicologist, 82, 1447.

[18] Bayse, G.S., Jinadu, L.A., Shaw, K.A. and Wiley, K.L. (2000) The N-acetylation of arsanilic acid in vitro by mammalian enzymes. Drug Metabolism and Disposition, 28, 487-492.

[19] O’Neil, M.J. (2006) The Merck Index: An Encyclopedia of Chemicals, Drugs and Biological. Merck and Company, Whitehouse Station.

[20] Harris, G. and Grady, D. (2011) Pfizer suspends sales of chicken drug with arsenic. New York Times, SB, 2.

[21] Ashby, J. and Tennant, R.W. (1991) Definitive relationships among chemical structure, carcinogenicity and mutagenicity for 301 chemicals tested by the US NTP. Mutation Research, 257, 229-306. doi:10.1016/0165-1110(91)90003-E

[22] Parkinson, A. (2001) Biotransformation of xenobiotics. In: Klaassen, C.D. Ed., Casarett and Doull's Toxicology, McGraw Hill, New York, 133-224.

[23] Bayse, G.S., Jackson, K.M., Kirlin, W.G. and RollinsHairston, A. (2006) Proliferation of human caco-2 cells mediated by $\mathrm{N}$-acetylation and oxidation reactions of 3 amino-4-hydroxybenzenearsonate. Toxicologist, 90, 674.

[24] Bayse, G.S., et al. (2007) Permeation of benzenearsonates provides sufficient concentrations to cause alterations in caco-2 cell proliferation. Toxicologist, 96, 1174.

[25] Robinson, D.K., Hammonds-Odie, L.P., Jackson, K.M., Kirlin, W.G. and Bayse, G.S. (2010) Caco-2 cell permeation of five benzenearsonates increases likelihood of hepatic biotransformations. Toxicologist, 114, 1101.

[26] Hammonds-Odie, L.P., Bayse, G.S., Jackson, K.M. and Robinson, D.K. (2006) Evaluation of benezenearsonate permeation in caco-2 cells.

http://www.fasebj.org/cgi/content/meeting_abstract/20/5/ LB111-b?sid=cf22ab74-c1a9-4417-b169-133f4b8aa2ce

[27] Artursson, P. (1990) Epithelial transport of drugs in cell culture. I: A model for studying the passive diffusion of drugs over intestinal absorptive (caco-2) cells. Journal of Pharmaceutical Sciences, 79, 476-482. doi:10.1002/jps.2600790604

[28] Hidalgo, I.J., Raub, T.J. and Borchardt, R.T. (1989) Characterization of the human colon carcinoma cell line (caco-2) as a model system for intestinal epithelial permeability. Gastroenterology, 96, 736-749.

[29] Prueksaritanont, T., Gorham, L.M., Hochman, J.H., Tran, L.O. and Vyas, K.P. (1996) Comparative studies of drug- 
metabolizing enzymes in dog, monkey, and human small intestines, and in caco- 2 cells. Drug Metabolism and Disposition, 24, 634-642.

[30] Hayes, J.R. and Campbell, T.C. (1986) Food additives and contaminants. In: Klaassen, C.D., Amdur, M.O. and Doull, J. Eds., Casarett and Doull's Toxicology, Macmillan, New York, 771-800.

[31] Abdo, K.M., et al. (1989) Toxic responses in F344 rats and $\mathrm{B} 6 \mathrm{CF}_{1}$ mice given roxarsone in their diets for up to 13 weeks. Toxicology Letters, 45, 5-66. doi:10.1016/0378-4274(89)90159-8

[32] Ashby, J. and Paton, D. (1993) The influence of chemical structure on the extent and sites of carcinogenesis for 522 rodent carcinogens and 55 different human carcinogen exposures. Mutation Research, 286, 3-74. doi:10.1016/0027-5107(93)90003-X

[33] US Environmental Protection Agency (2011) Region 4 should strengthen oversight of Georgia's concentrated animal feeding operation program.

http://www.epa.gov/oig/reports/2011/20110623-11-P-027 $\underline{4 . p d f}$

[34] Thompson, C.M., Haws, L.C., Harris, M.A., Gatto, N.M. and Proctor, D.M. (2011) Application of the US EPA mode of action framework for purposes of guiding future research: A case study involving the oral carcinogenicity of hexavalent chromium. Toxicological Sciences, 119, 20-40. doi:10.1093/toxsci/kfq320

[35] Doerge, D.R., Churchwell, M.I., Marques, M.M. and Beland, F.A. (1999) Quantitative analysis of 4-aminobiphenyl-C8-deoxyguanosyl DNA adducts produced in vitro using HPLC-ES-MS. Carcinogenesis, 20, 1055-1061. doi:10.1093/carcin/20.6.1055

[36] Zhang, T., Cao, E. and Qin, J. (2002) Opposite biological effects of arsenic trioxide and arsacetin involve a different regulation of signaling in human gastric cancer MGC803 cells. Pharmacology, 64, 160-168. doi:10.1159/000056166

[37] Park, W.H., et al. (2000) Arsenic trioxide-mediated growth inhibition in MC/CAR myeloma cells via cell cycle arrest in association with induction of cyclin-dependent kinase inhibitor, p21, and apoptosis. Cancer Research, 60, 3065-3071.

[38] Vogt, B.L. and Rossman, T.G. (2001) Effects of arsenite on p53, p21 and cyclin D expression in normal human fibroblasts-A possible mechanism for arsenite's comutagenicity. Mutation Research, 478, 159-168. doi:10.1016/S0027-5107(01)00137-3
[39] Barr, F.D., Krohmer, L.J., Hamilton, J.W. and Sheldon, L.A. (2009) Disruption of histone modification and CARM1 recruitment by arsenic represses transcription at glucocorticoid receptor-regulated promoters. PLOS ONE, 4, e6766. doi:10.1371/journal.pone.0006766

[40] Davey, J.C., et al. (2008) Arsenic as an endocrine disruptor: Arsenic disrupts retinoic acid receptor-and thyroid hormone receptor-mediated gene regulation and thyroid hormone-mediated amphibian tail metamorphosis. Environmental Health Perspectives, 116, 165-172.

[41] Kozul, C.D., et al. (2009) Chronic exposure to arsenic in the drinking water alters the expression of immune response genes in mouse lung. Environmental Health Perspectives, 117, 1108-1115. doi:10.1289/ehp.0800199

[42] Meharg, A.A. and Raab, A. (2010). Getting to the bottom of arsenic standards and guidelines. Environmental Science \& Technology, 44, 4395-4399. doi:10.1021/es9034304

[43] Tapio, S. and Grosche, B. (2006) Arsenic in the aetiology of cancer. Mutation Research, 612, 215-246. doi:10.1016/j.mrrev.2006.02.001

[44] Kozul-Horvath, C.D., Zandbergen, F., Jackson, B.P., Enelow, R.I. and Hamilton, J.W. (2012) Effects of lowdose drinking water arsenic on mouse fetal and postnatal growth and development. PLOS ONE, 7, e38249. doi:10.1371/journal.pone.0038249

[45] Price, L.B., et al. (2007) Elevated risk of carrying gentamicin-resistant Escherichia coli among US poultry workers. Environmental Health Perspectives, 115, 17381742. doi:10.1289/ehp.10191

[46] Sapkota, A.R., Price, L.B. and Silbergeld, E.K. (2006) Arsenic resistance in Campylobacter spp. isolated from retail poultry products. Applied and Environmental Microbiology, 72, 3069-3071. doi:10.1128/AEM.72.4.3069-3071.2006

[47] Marshall, B.M. and Levy, S.B. (2011) Food animals and antimicrobials: Impacts on human health. Clinical Microbiology Reviews, 2, 718-733. doi:10.1128/CMR.00002-11

[48] US Food and Drug Administration (2012) 21 CFR part 558 subpart B-specific new animal drugs for use in animal feeds. Electronic Code of Federal Regulations. http://www.gpo.gov/fdsys/pkg/CFR-2012-title21-vol6/pd f/CFR-2012-title21-vol6-sec558-530.pdf 